\title{
Transformation of Synthetic Allicin: The Influence of Ultrasound, Microwaves, Different Solvents and Temperatures, and the Products Isolation
}

\author{
Dušica Ilić, ${ }^{1}$ Vesna Nikolić, ${ }^{1}$ Mihajlo Stanković, ${ }^{1}$ Ljubiša Nikolić, ${ }^{1}$ Ljiljana Stanojević, ${ }^{1}$ \\ Ivana Mladenović-Ranisavljević, ${ }^{1}$ and Andrija Śmelcerovićc ${ }^{2}$ \\ ${ }^{1}$ Faculty of Technology, University of Niš, Leskovac, Serbia \\ ${ }^{2}$ Department of Pharmacy, Faculty of Medicine, University of Nǐ̌, Niš, Serbia \\ Correspondence should be addressed to Andrija Šmelcerović, a.smelcerovic@yahoo.com
}

Received 29 October 2011; Accepted 2 January 2012

Academic Editors: R. J. Tremont and M. C. Yebra-Biurrun

Copyright () 2012 Dušica Ilić et al. This is an open access article distributed under the Creative Commons Attribution License, which permits unrestricted use, distribution, and reproduction in any medium, provided the original work is properly cited.

The transformation of the synthesized allicin, using conventional method, the influence of ultrasound and microwaves, in different organic solvents (acetonitrile, acetone, methanol, and chloroform), at various temperatures (room temperature, $45^{\circ} \mathrm{C}$, and $55^{\circ} \mathrm{C}$ ) was investigated. Allicin degradation kinetic was monitored by HPLC. Allicin transformation under the effect of microwaves is faster than transformations performed under the influence of ultrasound or by conventional method. Increase of the temperature accelerates allicin transformation. Pharmacologically active compounds of (E)-ajoene, (Z)-ajoene, 3-vinyl-4H-1,2-dithiin, 2-vinyl$4 \mathrm{H}-1,3$-dithiin, and diallyl disulfide were isolated from the mixture of transformation products of allicin under the influence of microwaves in methanol at $55^{\circ} \mathrm{C}$, which is according to kinetic parameters (highest values of the order of reaction and the lowest activation energy) the optimal method.

\section{Introduction}

Allicin (3-prop-2-enylsulfinylsulfanylprop-1-ene) is a thioester of sulfenic acid, or allylthiosulfinate. It is an oily, light yellow liquid that has a distinctively pungent smell [1]. Allicin is the most important pharmacologically active substance of the fresh aqueous extract of garlic [2-4] which exhibits antimicrobial [5-10], antiviral [11], antioxidant [7], anticancer [12], antihypertensive [13], and hypolipidemic activity [13]. Isolation of allicin from garlic is a very complex and difficult process because of its instability. The synthesis of allicin is based on the oxidation of allyl disulfide with hydrogen peroxide in acidic media [14-17], the oxidation of allyl disulfide with 3-chloroperoxybenzoic acid in chloroform [18], and the oxidation of diallyl disulfide with magnesium peroxyhydrate in the presence of ammonium butyl sulphate [19]. In our previous paper on the synthesis of allicin [20] we proposed radical mechanism of allyl disulfide oxidation. Due to the significant instability of allicin, synthesis procedures are usually performed at temperatures from $0^{\circ} \mathrm{C}$ to $25^{\circ} \mathrm{C}$.
Allicin was more stable in $20 \%$ alcohol than in water, but surprisingly unstable in vegetable oil, with half-life activity of 0.8 hours [22]. In order to increase the stability of allicin, we obtained the inclusion complexes with $\beta$-cyclodextrin [8] and carbamide [9], where its pharmacological activity was still preserved. There are data about the transformation of allicin in the polar $[21,23]$ and nonpolar $[1,3,4]$ media, where active products with higher stability than allicin were obtained. In hexane or soybean oil, allicin forms ajoenes and vinyldithiins [4]. Block and collaborators have proposed degradation mechanisms of allicin to the above-mentioned products (Schemes 1 and 2) [21].

In our previous paper [7] we examined the stability of synthesized allicin by FTIR method, at room temperature. Herein, we present the influence of various factors (ultrasound, microwaves, different solvents, and temperatures) on the kinetics of transformation of allicin. To the best of our knowledge, this is the first report on the influence of ultrasound and microwaves on the allicin transformation. For the optimal transformation process, according to kinetic 

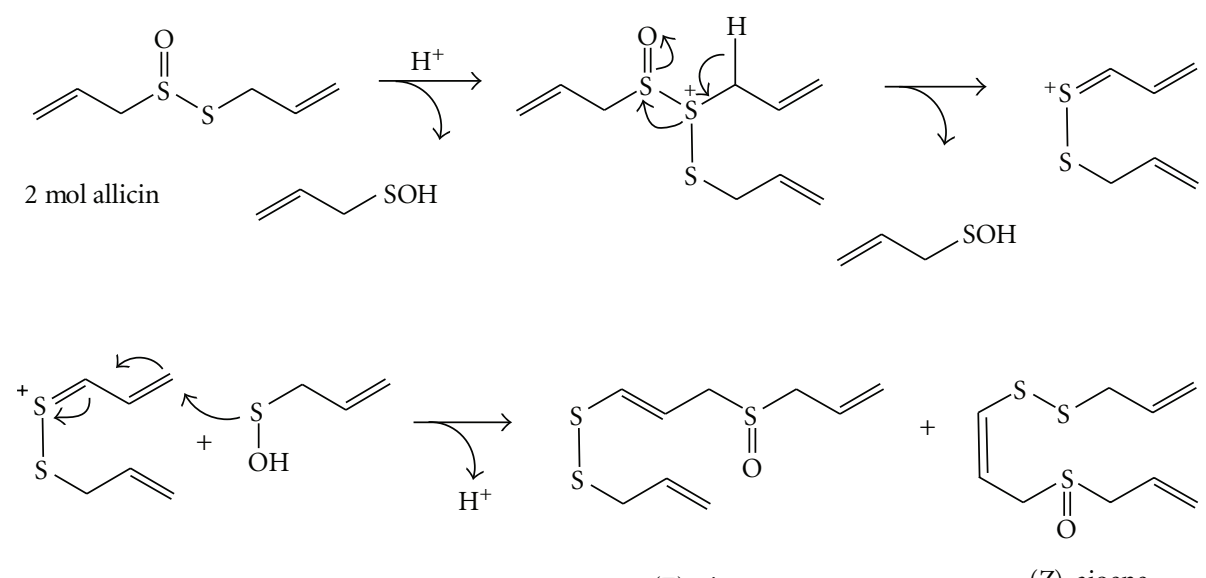

(E)-ajoene

(Z)-ajoene

Scheme 1: Mechanism of allicin transformation to ajoenes [21].
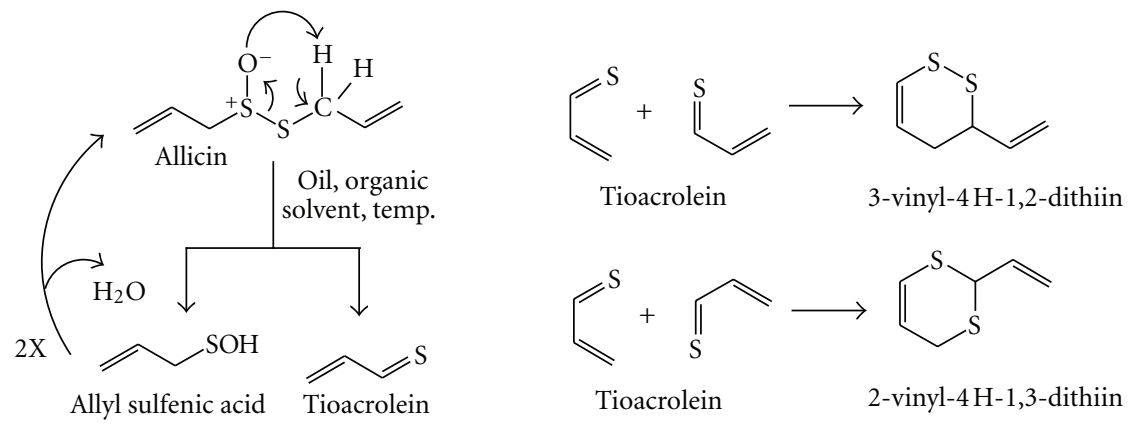

Scheme 2: Transformation of allicin in oil and organic nonpolar solvents [21].

parameters, from the mixture of transformation products by preparative HPLC method, predominant compounds were isolated. Their structures were determined by spectroscopic methods (UV, FTIR, NMR, and MS).

\section{Experimental}

2.1. Synthesis of Allicin. Allicin was synthesized according to our previous procedure [20]. Synthesis is based on the oxidation of allyl disulfide with the acidic hydrogen peroxide. Allicin was extracted from the crude reaction mixture using multiple liquid-liquid extraction with diethyl ether.

2.2. Transformation of Allicin in the Presence of Solvent at Room Temperature. Transformation of allicin (1 g) in organic solvents $\left(9 \mathrm{~cm}^{3}\right.$ of acetonitrile, acetone, methanol, or chloroform) was obtained using conventional method, the influence of ultrasound and microwaves.

Conventional transformation of allicin has been performed for seven days at room temperature and by heating in a water bath with reflux at $45^{\circ} \mathrm{C}$ and $55^{\circ} \mathrm{C}$.

Transformation under the influence of ultrasound was performed in the ultrasonic bath (Sonic, Nis, Serbia; total nominal power: $3 \times 50 \mathrm{~W}$; dimensions of the bath: $30 \times 15 \times$ $20 \mathrm{~cm}$ ) at the frequency of $40 \mathrm{kHz}$, with reflux at $45^{\circ} \mathrm{C}$ and $55^{\circ} \mathrm{C}$.
Transformation under the effect of microwaves was performed in a "Discover" focus microwave reactor (CEM Corporation, Matthews, NC, USA), at a frequency of $2.45 \mathrm{GHz}$, with power of $150 \mathrm{~W}$, at $45^{\circ} \mathrm{C}$ and $55^{\circ} \mathrm{C}$.

2.3. Determination of Allicin Content. The content of allicin was analyzed using HPLC-UV method. Chromatographic analysis was performed using Agilent 1100 system equipped with an Agilent 1200 autosampler. Separations were performed on Zorbax Eclipse XDB-C18 $(4.6 \times 250 \mathrm{~mm}, 5 \mu \mathrm{m})$ column (Agilent, Santa Clara, USA). The mobile phase consisted of acetonitrile and water, $80: 20$, v/v. The flow rate was $1 \mathrm{~mL} / \mathrm{min}$ and the injection volume was $20 \mu \mathrm{L}$. All separations were performed at $25^{\circ} \mathrm{C}$. DAD detection was performed using a surveyor Agilent photodiode array detector at $205 \mathrm{~nm}$.

External calibration was performed in the range of $12.5 \mu \mathrm{g} / \mathrm{mL}$ to $250 \mu \mathrm{g} / \mathrm{mL}$. Within the range of concentrations injected, the detector response (peak area) was linear. Correlation coefficient for the calibration curve was 0.998 .

2.4. Isolation and Structural Determination of Transformation Products. Isolation of transformation products was performed using preparative HPLC chromatography, on the Agilent Technologies 1200 Series device. Separations were performed on a Zorbax XDB-C-18 $(6.2 \times 150 \mathrm{~mm}, 5 \mu \mathrm{m})$ 
column (Agilent, Santa Clara, USA). The mobile phase is consisted of acetonitrile and water, $80: 20$, v/v. The flow rate was $4 \mathrm{~mL} / \mathrm{min}$ and the injection volume was $70 \mu \mathrm{L}$. Seventy separations were performed at $25^{\circ} \mathrm{C}$. DAD detection was performed using a surveyor Agilent photodiode array detector at $205 \mathrm{~nm}$. For each isolated component an UV spectrum has been recorded.

FTIR spectra were recorded at Bomem MB-100 spectrophotometer (Hartmann \& Braun, Baptiste, Canada) using the $\mathrm{KBr}$ technique in the range of $4000-400 \mathrm{~cm}^{-1}$.

${ }^{1} \mathrm{H}-\mathrm{NMR}$ and ${ }^{13} \mathrm{C}-\mathrm{NMR}$ measurements were performed by a Bruker AC 250E (Bruker, Germany) spectrometer at the operating frequencies of $250 \mathrm{MHz}$ and $62.5 \mathrm{MHz}$, respectively, using deuterated chloroform as solvent.

MS analysis of allicin transformation products was performed using a LCQ Fleet Ion Trap LC-MS ${ }^{\mathrm{n}}$ system (Thermo Scientific, San Jose, USA). Chromatographic conditions were identical with those of the determination of allicin content. Mass spectra were obtained in positive ionization mode using an extractor voltage of $4.5 \mathrm{kV}$.

\section{Results and Discussion}

Figure 1 shows changes in concentrations of allicin during the time, at room temperature, in acetonitrile, acetone, methanol, and chloroform. The most significant change of the allicin concentration occurs in the first five days in all solvents used. The lowest concentration of allicin remaining was detected in acetonitrile, while the highest concentration was detected in chloroform. Transformation of allicin in the above-mentioned solvents, using conventional method at higher temperatures $\left(45^{\circ} \mathrm{C}\right.$ and $\left.55^{\circ} \mathrm{C}\right)$, was significantly faster than the same process at room temperature (Figure 2). The most significant change of the allicin concentration in acetonitrile was achieved in about 75 minutes, while in chloroform it was achieved in about 120 minutes. Also, after the transformation at temperature of $55^{\circ} \mathrm{C}$ the lower concentrations of allicin remaining were detected in all solvents used compared to the results obtained at room temperature.

Transformation of allicin under the influence of ultrasound (Figure 3 ) occurs three to four times faster compared to the conventional process of transformation in all solvents used. In these transformations, as well as in conventional ones, the lowest concentration of the allicin remaining was found in acetonitrile.

Microwaves have a bigger impact on the transformation rate, compared to the ultrasound and the conventional process, for the same temperatures and solvents used (Figure 4). The fastest transformation including the complete transformation of allicin was achieved in methanol at $55^{\circ} \mathrm{C}$ in about 2 minutes.

In order to be able to compare the abilities of different solvents to generate heat from microwave irradiation, their capabilities to absorb microwave energy and to convert the absorbed energy into heat, must be taken into account. Those factors may be considered using the loss angle, $\delta$, which is usually expressed in the form of its tangent

$$
\tan \delta=\frac{\varepsilon^{\prime \prime}}{\varepsilon^{\prime}} .
$$

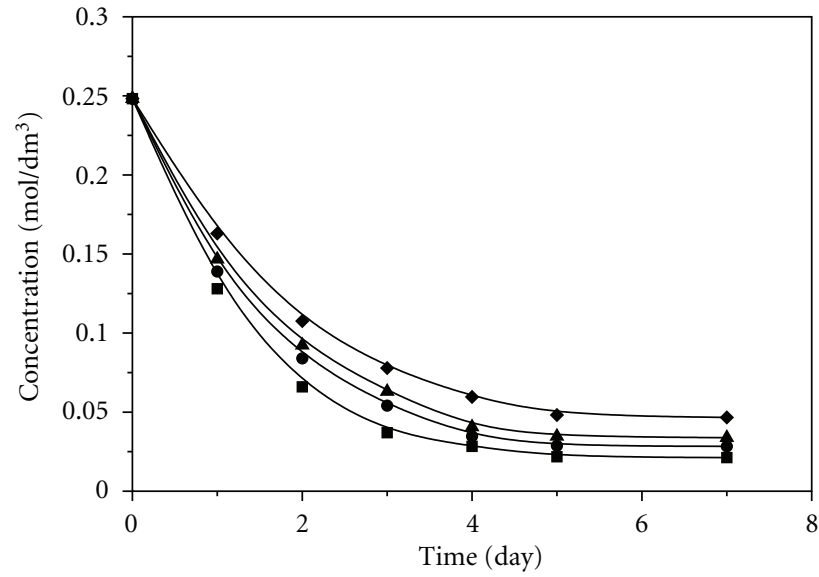

FIGURE 1: Change of allicin concentrations in acetonitrile, acetone, chloroform, and methanol at room temperature ( Acetonitrile; • Acetone; $\boldsymbol{\Delta}$ Methanol $55^{\circ} \mathrm{C} ;$ Chloroform).

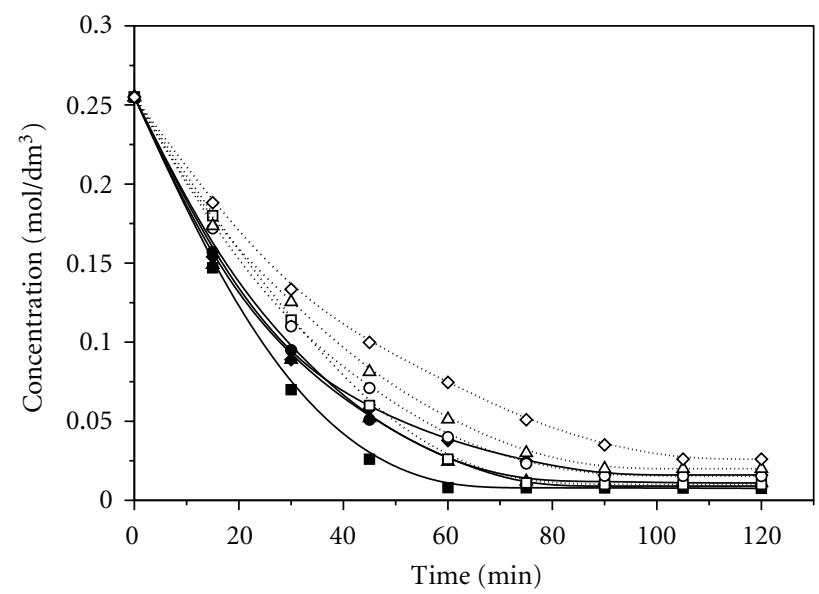

FIGURE 2: Change of the allicin concentration using conventional heating at $45^{\circ} \mathrm{C}$ and $55^{\circ} \mathrm{C}\left(\boldsymbol{\square}\right.$ Acetonitrile $55^{\circ} \mathrm{C} ; \square$ Acetonitrile $45^{\circ} \mathrm{C}$; - Acetone $55^{\circ} \mathrm{C}$; 。 Acetone $45^{\circ} \mathrm{C}$; $\Delta$ Methanol $55^{\circ} \mathrm{C}$; $\triangle$ Methanol $45^{\circ} \mathrm{C}$; Chloroform $55^{\circ} \mathrm{C}$; $\diamond$ Chloroform $45^{\circ} \mathrm{C}$ ).

The dielectric constant, $\varepsilon^{\prime}$, represents the ability of dielectric material to store electrical potential energy under the influence of an electric field. The loss factor, $\varepsilon^{\prime \prime}$, quantifies the efficiency with which the absorbed energy is converted into heat [24]. The transformation of allicin occurs fastest in methanol which can be explained by the fact that this solvent has a much higher value of $\delta(0.659)$ compared to the other three solvents, whose $\delta$ values range from 0.054 to 0.091 [24].

Kinetic parameters of allicin transformations were determined by the reaction rate equation

$$
-\frac{d C_{A}}{d t}=k \cdot C_{A}^{n}
$$

Logarithm of this equation is given in (3). By using this equation, kinetic parameters of the reaction of allicin transformation, chemical reaction rate constant $(k)$, and order of reaction $(n)$ can be determined

$$
\ln \left(-\frac{d C_{A}}{d t}\right)=\ln (k)+n \cdot \ln \left(C_{A}\right) .
$$


TABle 1: Spectral data for the components isolated from the mixture of allicin transformation products obtained under the effect of microwaves in methanol at $55^{\circ} \mathrm{C}$.

\begin{tabular}{|c|c|c|c|c|c|}
\hline Name and structure of compounds & ${ }^{1} \mathrm{H} \operatorname{NMR}(\delta, \mathrm{ppm})$ & $\begin{array}{c}{ }^{13} \mathrm{C} \text { NMR } \\
(\delta, \mathrm{ppm})\end{array}$ & $\operatorname{FTIR}\left(\mathrm{cm}^{-1}\right)$ & MS $(\mathrm{m} / \mathrm{z})$ & $\begin{array}{l}\text { UV } \\
(\mathrm{nm})\end{array}$ \\
\hline 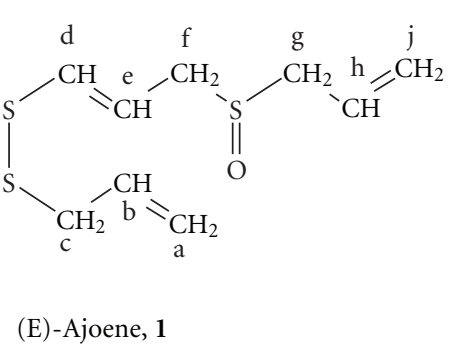 & $\begin{array}{c}6.38(=\mathrm{CH}-\mathrm{S}-\mathrm{S}, \mathrm{d}) \\
5.9\left(=\underline{\mathrm{CH}}-\mathrm{CH}_{2}, \mathrm{~m}\right) \\
5.4\left(\mathrm{CH}_{2}=\underline{\mathrm{CH}}-\mathrm{CH}_{2}-\mathrm{SO}, \mathrm{m}\right) \\
5.2\left(\mathrm{CH}_{2}=\underline{\mathrm{CH}}-\mathrm{CH}_{2}-\mathrm{S}, \mathrm{m}\right) \\
3.5\left(-\mathrm{CH}_{2}-\mathrm{SO}-\mathrm{CH}_{2}-, \mathrm{m}\right) \\
3.36\left(-\mathrm{S}-\mathrm{S}-\mathrm{CH}_{2}-, \mathrm{d}\right)\end{array}$ & $\begin{array}{l}41.5(\mathrm{c}) \\
53(\mathrm{f}) \\
54.5(\mathrm{~g}) \\
117(\mathrm{~b}) \\
119.5(\mathrm{e}) \\
123.8(\mathrm{~h}) \\
126(\mathrm{~d}) \\
132.5(\mathrm{a}) \\
135(\mathrm{j})\end{array}$ & $\begin{array}{c}3081(\mathrm{w}, \mathrm{C}-\mathrm{H}) \\
3000-2856(\mathrm{~s}) \\
1636(\mathrm{w}) \\
1563(\mathrm{w}) \\
1435(\mathrm{~m}) \\
1051(\mathrm{~s}, \mathrm{CS}(\mathrm{O}) \mathrm{C})\end{array}$ & $\begin{array}{c}234(10), 145(24), \\
111(11), 103(91), \\
73(39), 68(32), 45 \\
(100), 41(91)\end{array}$ & 244 \\
\hline 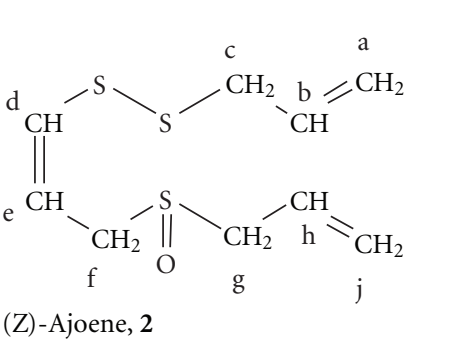 & $\begin{array}{c}6.56(=\mathrm{CH}-\mathrm{S}-\mathrm{S}, \mathrm{d}) \\
5.8\left(=\underline{\mathrm{CH}}-\mathrm{CH}_{2}, \mathrm{~m}\right) \\
5.4\left(\mathrm{CH}_{2}=\underline{\mathrm{CH}}-\mathrm{CH}_{2}-\mathrm{SO}, \mathrm{m}\right) \\
5.2\left(\mathrm{CH}_{2}=\underline{\mathrm{CH}}-\mathrm{CH}_{2}-\mathrm{S}, \mathrm{m}\right) \\
3.5\left(-\mathrm{CH}_{2}-\mathrm{SO}-\mathrm{CH}_{2}-, \mathrm{m}\right) \\
3.38\left(-\mathrm{S}-\mathrm{S}-\mathrm{CH}_{2}-, \mathrm{d}\right)\end{array}$ & $\begin{array}{l}42.1(\mathrm{c}) \\
50(\mathrm{f}) \\
55(\mathrm{~g}) \\
118.2(\mathrm{~b}) \\
119.5(\mathrm{e}) \\
124(\mathrm{~h}) \\
126(\mathrm{~d}) \\
132.5(\mathrm{a}) \\
138.5(\mathrm{j})\end{array}$ & $\begin{array}{c}3081(\mathrm{w}, \mathrm{C}-\mathrm{H}) \\
3000-2856(\mathrm{~s}) \\
1636(\mathrm{~m}) \\
1455(\mathrm{~m}) \\
1402(\mathrm{~m}) \\
1045(\mathrm{~s}, \mathrm{CS}(\mathrm{O}) \mathrm{C}) \\
926(\mathrm{~s})\end{array}$ & $\begin{array}{c}234(10), 145(22), \\
111(13), 103(93), \\
73(39), 68(37), 45 \\
(100), 41(91)\end{array}$ & 235 \\
\hline 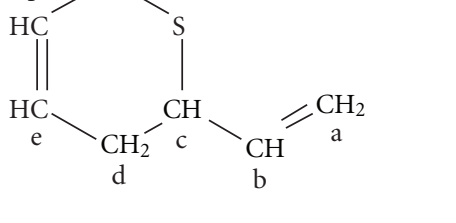 & $\begin{array}{c}6.31(\mathrm{~S}-\mathrm{CH}=\mathrm{C}, \mathrm{d}) \\
6.01(-\mathrm{CH}=, \mathrm{m}) \\
3.35\left(-\mathrm{CH}_{2}-, \mathrm{m}\right) \\
4.51(-\mathrm{CH}-, \mathrm{m}) \\
5.85(-\mathrm{CH}=, \mathrm{m}) \\
5.36\left(\mathrm{CH}_{2}=, \mathrm{d}\right)\end{array}$ & $\begin{array}{l}132.5(\mathrm{a}) \\
121.99(\mathrm{f}) \\
118(\mathrm{e}) \\
117.1(\mathrm{~b}) \\
44.5(\mathrm{~d}) \\
39.1(\mathrm{c})\end{array}$ & $\begin{array}{c}3081(\mathrm{~m}, \mathrm{C}-\mathrm{H}) \\
3012(\mathrm{~m}, \mathrm{C}=\mathrm{CH}) \\
2978\left(\mathrm{~m}, \mathrm{C}=\mathrm{CH}_{2}\right) \\
1634(\mathrm{~s}, \mathrm{C}=\mathrm{C}) \\
982(\mathrm{~s}) \\
917(\mathrm{~s})\end{array}$ & $\begin{array}{c}144(49), 111(75), \\
103(31), 97(48), \\
72(25), 71(60), 45 \\
\quad(100), 39(20)\end{array}$ & 227 \\
\hline
\end{tabular}

3-Vinyl-4 H-1,2-dithiin, 3

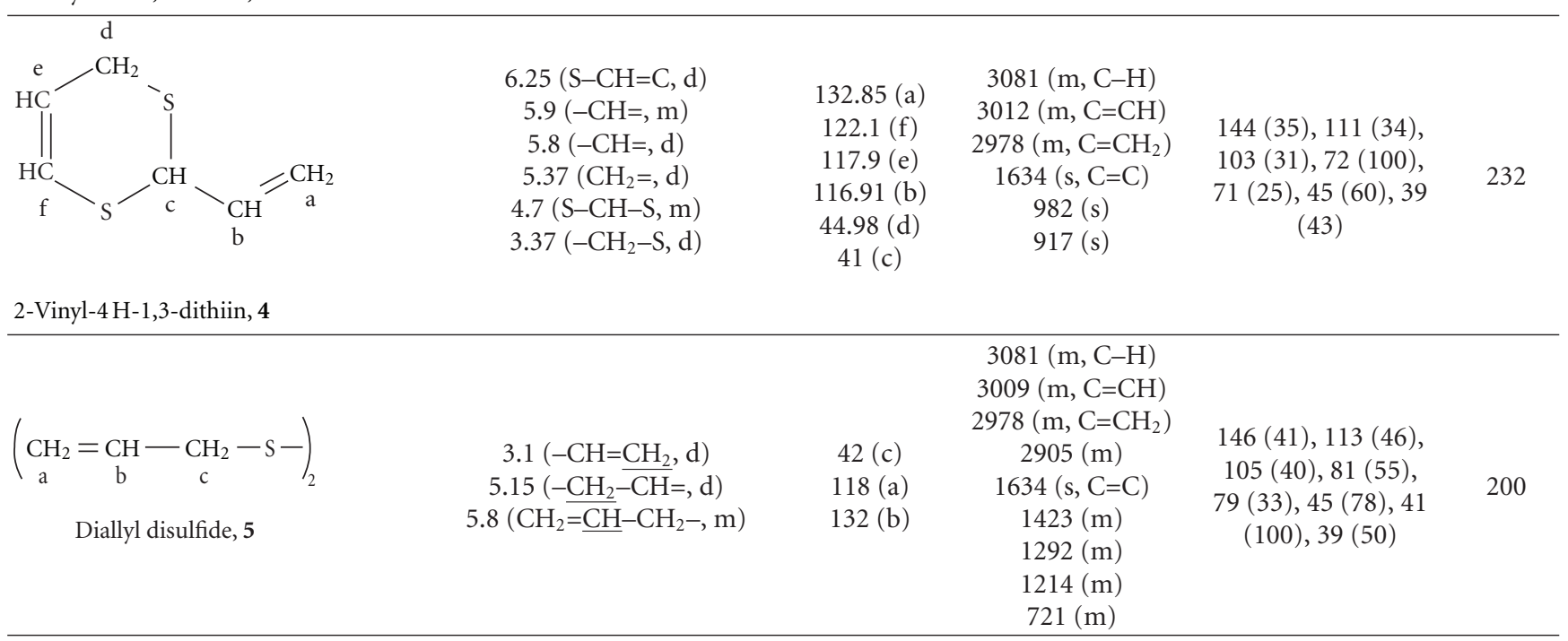

For all the transformations, dependence $\ln \left(-d C_{A} / d t\right)$ of $\ln \left(C_{A}\right)$ is shown in Figure 5. Activation energy (Ea) was determined from Arrhenius's equation

$$
k=A \cdot e^{-\mathrm{Ea} / R T} .
$$

The changes of Ea and $n$ for the applied solvents and techniques of allicin transformation are shown in Figure 6. Under the effect of microwaves in all solvents used, the highest value of $n$ (1.5) is achieved. Under the influence of ultrasound $n$ equals 1 , while in the conventional process it equals 0.5 . The highest values of $\mathrm{Ea}$ are required for the conventional method of allicin transformation, while the lowest Ea values are required for the process under the effect of microwaves. According to Ea values, the most suitable allicin transformation process is performed under the influence of microwaves in methanol at $55^{\circ} \mathrm{C}(\mathrm{Ea}=7902 \mathrm{~J} / \mathrm{mol})$. Also, 


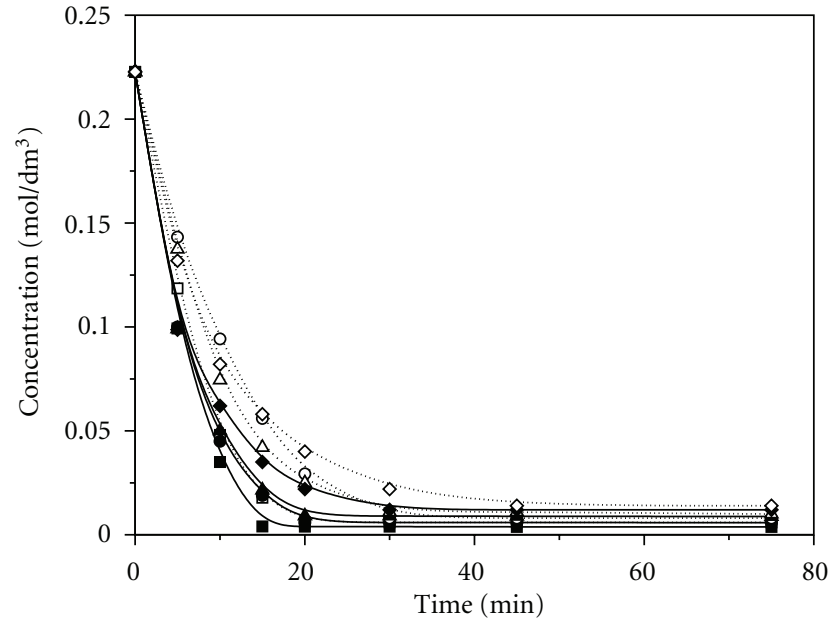

FIGURE 3: Change of the allicin concentration under the influence of ultrasound at $45^{\circ} \mathrm{C}$ and $55^{\circ} \mathrm{C}\left(\square\right.$ Acetonitrile $55^{\circ} \mathrm{C} ; \square$ Acetonitrile $45^{\circ} \mathrm{C}$; - Acetone $55^{\circ} \mathrm{C}$; 。 Acetone $45^{\circ} \mathrm{C}$; $\Delta$ Methanol $55^{\circ} \mathrm{C}$; $\triangle$ Methanol $45^{\circ} \mathrm{C}$; Chloroform $55^{\circ} \mathrm{C}$; $\diamond$ Chloroform $5^{\circ} \mathrm{C}$ ).

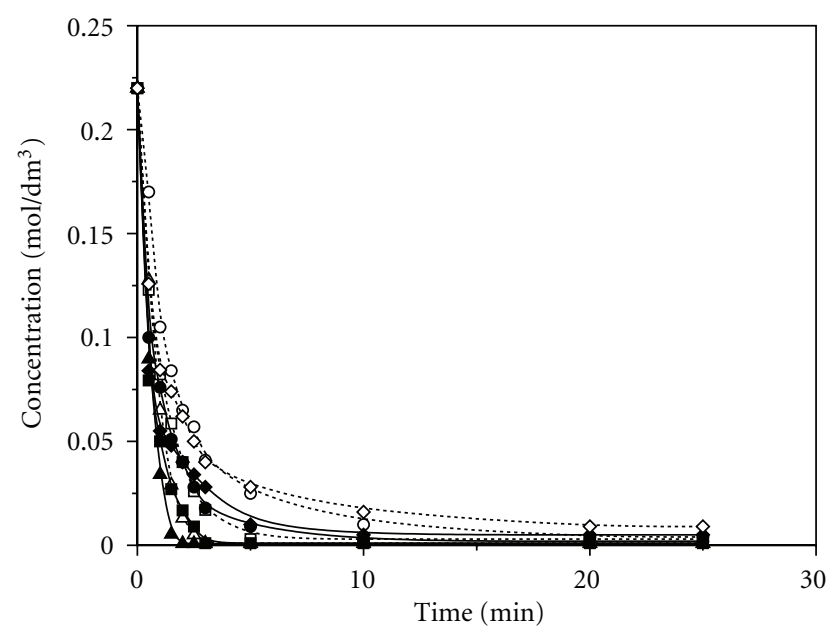

Figure 4: Change of allicin concentration under the influence of microwaves at $45^{\circ} \mathrm{C}$ and $55^{\circ} \mathrm{C}\left(\square\right.$ Acetonitrile $55^{\circ} \mathrm{C}$; $\square$ Acetonitrile $45^{\circ} \mathrm{C}$; - Acetone $55^{\circ} \mathrm{C}$; 。 Acetone $45^{\circ} \mathrm{C}$; $\Delta$ Methanol $55^{\circ} \mathrm{C} ; \triangle$ Methanol $45^{\circ} \mathrm{C}$; Chloroform $55^{\circ} \mathrm{C}$; $\diamond$ Chloroform $45^{\circ} \mathrm{C}$ ).

this process occurs within the shortest transformation time (about 2 minutes). The highest Ea value is required for the conventional procedure in chloroform at $45^{\circ} \mathrm{C}(\mathrm{Ea}=$ $70645 \mathrm{~J} / \mathrm{mol}$ ) and this process requires the longest time of transformation. Therefore, these conditions are least suitable for allicin transformation.

The most common components (see Figure 7) from the mixture of transformation products of allicin under the influence of microwaves in methanol at $55^{\circ} \mathrm{C}$ were isolated using preparative HPLC chromatography. Their structures were determined by UV, FTIR, NMR, and MS methods and spectroscopic data are given in Table 1. (E)-Ajoene ((E)-1(prop-2-enyldisulfanyl)-3-prop-2-enylsulfinylprop-1-ene;

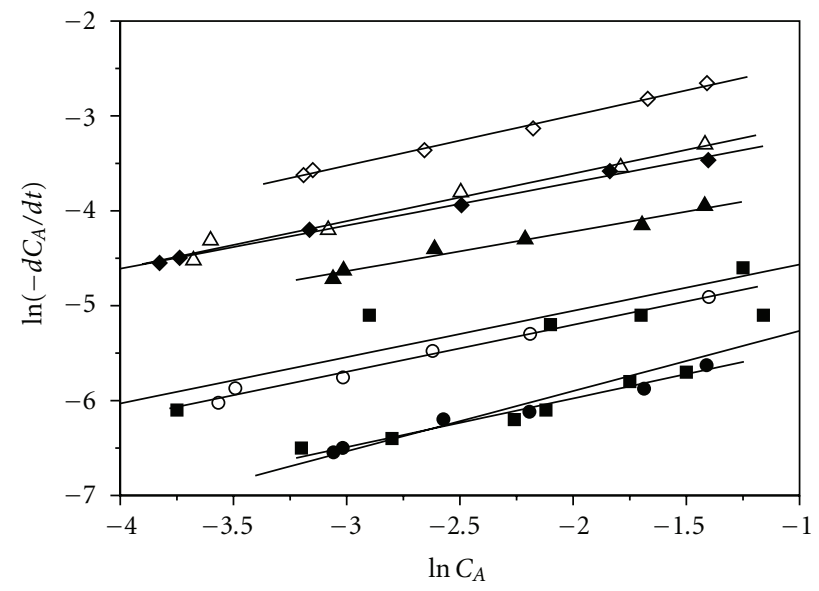

(a)

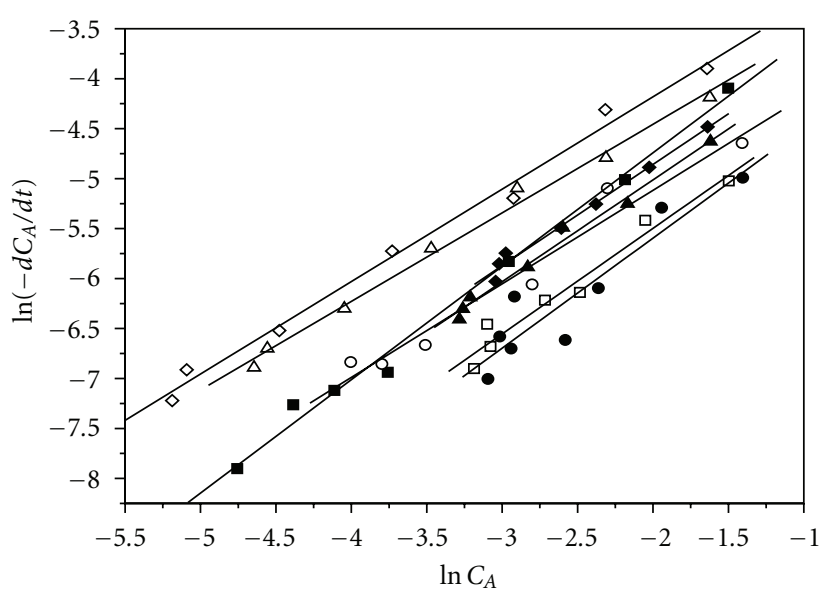

(b)

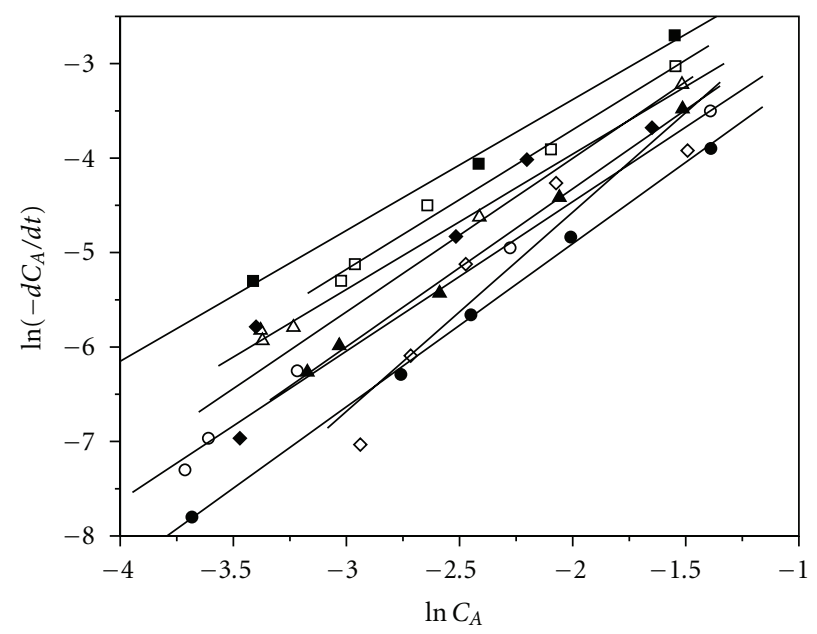

(c)

Figure 5: Dependence $\ln \left(-d C_{A} / d t\right)$ of $\ln \left(C_{A}\right)$ for the allicin transformation by conventional method (a), under the influence of ultrasound (b) and microwaves (c). ( $\square$ Acetonitrile $55^{\circ} \mathrm{C}$; $\square$ Acetonitrile $45^{\circ} \mathrm{C}$; $\bullet$ Acetone $55^{\circ} \mathrm{C}$; 。 Acetone $45^{\circ} \mathrm{C}$; $\boldsymbol{\Delta}$ Methanol $55^{\circ} \mathrm{C}$; $\triangle$ Methanol $45^{\circ} \mathrm{C}$; Chloroform $55^{\circ} \mathrm{C}$; $\diamond$ Chloroform $45^{\circ} \mathrm{C}$ ). 


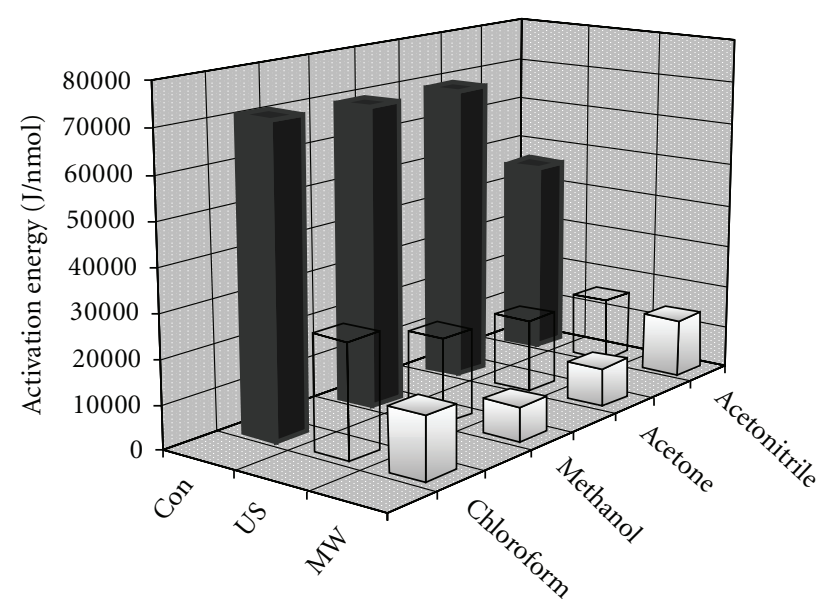

(a)

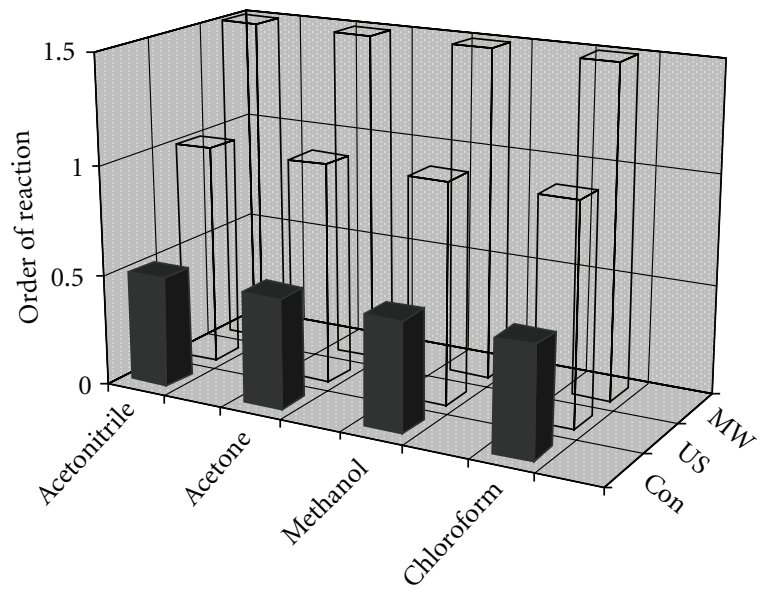

(b)

Figure 6: Values of Ea (a) and $n$ (b) for the allicin transformation by conventional method (Con), under the influence of ultrasound (US) and microwaves (MW).

(1), (Z)-ajoene ((Z)-1-(prop-2-enyldisulfanyl)-3-prop2-enylsulfinylprop-1-ene; (2), 3-vinyl-4H-1,2-dithiin (3ethenyl-3,4-dihydrodithiine; (3), 2-vinyl-4H-1,3-dithiin (2ethenyl-4H-1,3-dithiine; (4), and diallyl disulfide (3-(prop2-enyldisulfanyl)prop-1-ene; (5) were isolated. 1 and 2 exhibit antimicrobial $[25,26]$ and anticancer effect $[27,28]$. 3 and 4 participate in the inhibition of thrombocyte aggregation, cyclooxygenase and 5-lipoxygenase inhibition, and regulation of systolic and diastolic blood pressure [29]. 5 inhibits 1,2-dimethylhydrazine-induced colon and liver cancer in rodents [30]. Presence of these compounds in the transformation mixture is in accordance with the previous findings about the ways of allicin transformation [20].

Due to the complexity of the mixture of transformation products other compounds could not be isolated.

\section{Conclusion}

The transformation rate of allicin depends on the applied techniques of transformation, temperature, and solvents

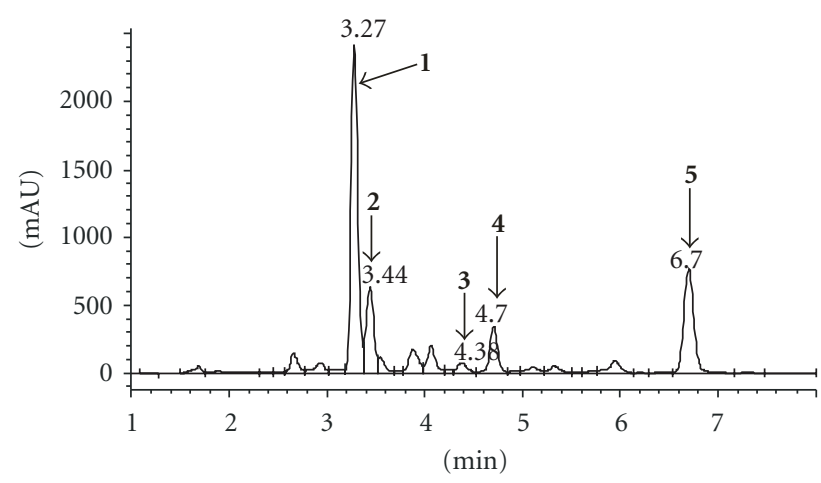

FIGURE 7: HPLC chromatogram of the mixture of allicin transformation products obtained under the effect of microwaves in methanol at $55^{\circ} \mathrm{C}((\mathrm{E})$-ajoene (1); (Z)-ajoene (2); 3-vinyl-4H-1,2dithiin (3); 2-vinyl-4H-1,3-dithiin (4); dialildisulfid (5)).

nature. Use of microwaves and increased temperatures accelerate the allicin transformation. Kinetic parameters, $n$ and Ea, depend on the transformation techniques used. The highest $n$ and the lowest Ea values were achieved under the influence of microwaves in methanol at temperature of $55^{\circ} \mathrm{C}$.

\section{Acknowledgment}

This work was supported by the Ministry of Education and Science of the Republic of Serbia (Project TR 34012).

\section{References}

[1] O. Sticher, "Beurteilung von Knoblauchpraparaten," Deutsche Apotheker-Zeitung, vol. 131, pp. 403-413, 1991.

[2] J. Koch, L. Berger, and C. V. Reiter, "Allicin in garlic (Allium sativum L.) and garlic preparation: quantitative determination using headspace gas chromatograph," Planta Medica, vol. 55, pp. 327-331, 1989.

[3] L. D. Lawson, S. G. Wood, and B. G. Hughes, "HPLC analysis of allicin and other thiosulfinates in garlic clove homogenates," Planta Medica, vol. 57, no. 3, pp. 263-270, 1991.

[4] L. D. Lawson, Z. Y. J. Wang, and B. G. Hughes, "Identification and HPLC quantitation of the sulfides and dialk(en)yl thiosulfinates in commercial garlic products," Planta Medica, vol. 57, no. 4, pp. 363-370, 1991.

[5] Y. Uchida, T. Takahashi, and N. Sato, "The characteristics of the antibacterial activity of garlic," Japanese Journal of Antibiotics, vol. 28, no. 4, pp. 638-642, 1975.

[6] H. Amagase, B. L. Petesch, H. Matsuura, S. Kasuga, and Y. Itakura, "Intake of garlic and its bioactive components," Journal of Nutrition, vol. 131, no. 3, pp. 955S-962S, 2001.

[7] D. P. Ilić, V. D. Nikolić, L. B. Nikolić, M. Z. Stanković, and L. P. Stanojević, "Thermal degradation, antioxidant and antimicrobial activity of the synthesized allicin and allicin incorporated in gel," Hemijska Industrija, vol. 64, no. 2, pp. 85-91, 2010.

[8] V. D. Nikolić, M. Stanković, A. Kapor, Lj. Nikolić, D. Cvetković, and J. Stamenković, "Allylthiosulfinate: $\beta$-cyclodextrin inclusion complex: preparation, characterization and microbiological activity," Pharmazie, vol. 59, no. 11, pp. 845848, 2004. 
[9] V. Nikolić, M. Stanković, L. J. Nikolić, D. Cvetković, A. Kapor, and M. Cakić, "The canal inclusion complex of allicin with carbamide: preparation, characterization and microbiological investigation," Chemical Industry and Chemical Engineering Quarterly, vol. 2, pp. 69-73, 2005.

[10] Z. M. Ross, E. A. O’Gara, D. J. Hill, H. V. Sleightholme, and D. J. Maslin, "Antimicrobial properties of garlic oil against human enteric bacteria: evaluation of methodologies and comparisons with garlic oil sulfides and garlic powder," Applied and Environmental Microbiology, vol. 67, no. 1, pp. 475-480, 2001.

[11] Y. Tsai, L. L. Cole, L. E. Davis, S. J. Lockwood, V. Simmons, and G. C. Wild, "Antiviral properties of garlic: in vitro effects on influenza B, herpes simplex and coxsackie viruses," Planta Medica, no. 5, pp. 460-461, 1985.

[12] T. Miron, M. Wilchek, A. Sharp et al., "Allicin inhibits cell growth and induces apoptosis through the mitochondrial pathway in HL60 and U937 cells," Journal of Nutritional Biochemistry, vol. 19, no. 8, pp. 524-535, 2008.

[13] K. L. Miller, R. S. Liebowitz, and L. K. Newby, "Complementary and alternative medicine in cardiovascular disease: a review of biologically based approaches," American Heart Journal, vol. 147, no. 3, pp. 401-411, 2004.

[14] C. J. Cavallito and J. H. Bailey, "Allicin, the antibacterial principle of Allium sativum. I. Isolation, physical properties and antibacterial action," Journal of the American Chemical Society, vol. 66, no. 11, pp. 1944-1952, 1944.

[15] B. Iberl, G. Winkler, B. Muller, and K. Knobloch, "Quantitative determination of allicin and alliin from garlic by HPLC," Planta Medica, vol. 56, no. 3, pp. 320-326, 1990.

[16] F. Freeman and Y. Kodera, "Garlic chemistry: stability of S(2-propenyl) 2-propene-1-sulfinothioate (allicin) in blood, solvents, and simulated physiological fluids," Journal of Agricultural and Food Chemistry, vol. 43, no. 9, pp. 2332-2338, 1995.

[17] E. Vedejs, T. H. Eberlein, and D. L. Varie, "Dienophilic thioaldehydes," Journal of the American Chemical Society, vol. 104, no. 5, pp. 1445-1447, 1982.

[18] H. Jansen, B. Muller, and K. Knobloch, "Allicin characterization and its determination by HPLC," Planta Medica, vol. 53, no. 6, pp. 559-562, 1987.

[19] G. Cruz-Villalon, "Synthesis of allicin and purification by solid-phase extraction," Analytical Biochemistry, vol. 290, no. 2, pp. 376-378, 2001.

[20] V. Nikolić, M. Stanković, L. J. Nikolić, and D. Cvetković, "Mechanism and kinetics of synthesis of allicin," Pharmazie, vol. 59, no. 1, pp. 10-14, 2004.

[21] E. Block, S. Ahmad, J. L. Cataltamo, M. K. Jain, and R. Apitz-Castro, "The chemistry of alkyl thiosulfinate esters. 9. Antithrombotic organosulfur compounds from garlic: structural, mechanistic, and synthetic studies," Journal of the American Chemical Society, vol. 108, pp. 7045-7055, 1986.

[22] H. Fujisawa, K. Suma, K. Origuchi, H. Kumagai, T. Seki, and T. Ariga, "Biological and chemical stability of garlic-derived allicin," Journal of Agricultural and Food Chemistry, vol. 56, no. 11, pp. 4229-4235, 2008.

[23] C. Egen-Schwind, R. Eckard, F. W. Jekat, and H. Winterhoff, "Pharmacokinetics of vinyldithiins, transformation products of allicin," Planta Medica, vol. 58, no. 1, pp. 8-13, 1992.

[24] P. Lidström, J. Tierney, B. Wathey, and J. Westman, "Microwave assisted organic synthesis-a review," Tetrahedron, vol. 57, no. 45, pp. 9225-9283, 2001.

[25] R. Walder, Z. Kalvatchev, D. Garzaro, M. Barrios, and R. Apitz-Castro, "In vitro suppression of HIV-1 replication by ajoene [(e)-(z)-4,5,9-trithiadodeca-1,6,11-triene-9 oxide]," Biomedicine and Pharmacotherapy, vol. 51, no. 9, pp. 397-403, 1997.

[26] P. Canizares, I. Gracia, L. A. Gomez et al., "Allyl-thiosulfanates, the bacteriostatic compounds of garlic against Helicobacter pylori," Biotechnology Progress, vol. 20, pp. 32-37, 2004.

[27] M. Li, J. M. Min, J. R. Cui et al., "Z-ajoene induces apoptosis of HL-60 cells: involvement of Bcl-2 cleavage," Nutrition and Cancer, vol. 42, no. 2, pp. 241-247, 2002.

[28] C. M. L. J. Tilli, A. J. W. Stavast-Kooy, J. D. D. Vuerstaek et al., "The garlic-derived organosulfur component ajoene decreases basal cell carcinoma tumor size by inducing apoptosis," Archives of Dermatological Research, vol. 295, no. 3, pp. 117123, 2003.

[29] N. D. Weber, D. O. Andersen, J. A. North, B. K. Murray, L. D. Lawson, and B. G. Hughes, "in vitro virucidal effects of Allium sativum (garlic) extract and compounds," Planta Medica, vol. 58, no. 5, pp. 417-423, 1992.

[30] J. F. Brady, D. Li, H. Ishizaki, and C. S. Yang, "Effect of diallyl sulfide on rat liver microsomal nitrosamine metabolism and other monooxygenase activities," Cancer Research, vol. 48, no. 21, pp. 5937-5940, 1988. 


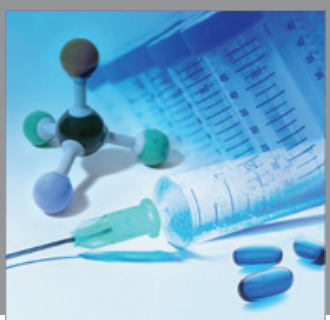

International Journal of

Medicinal Chemistry

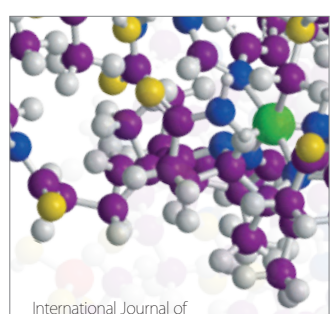

Carbohydrate Chemistry

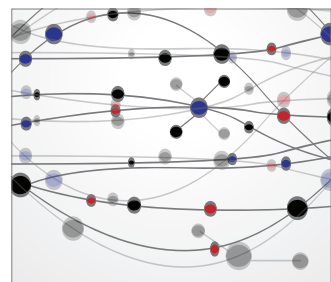

The Scientific World Journal
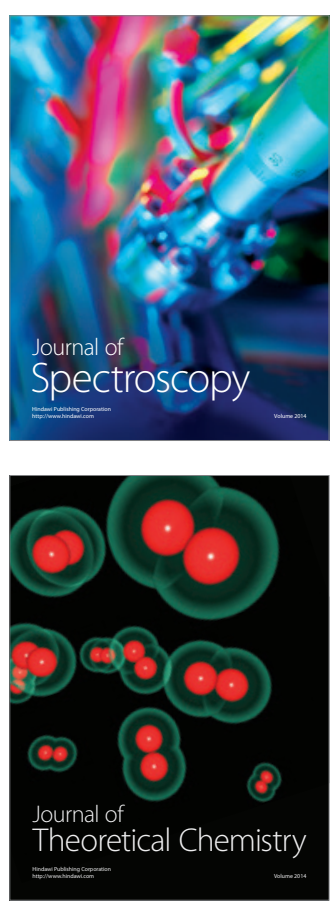
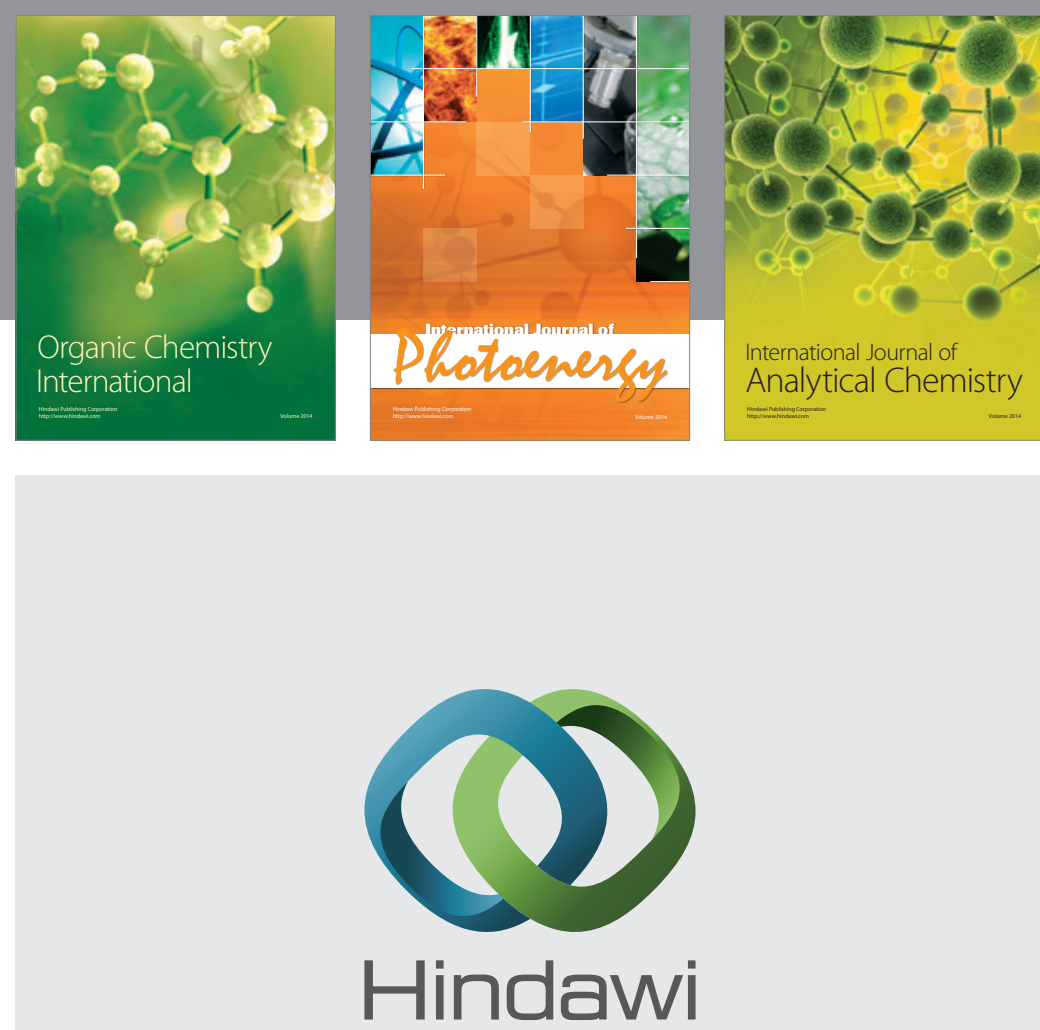

Submit your manuscripts at

http://www.hindawi.com
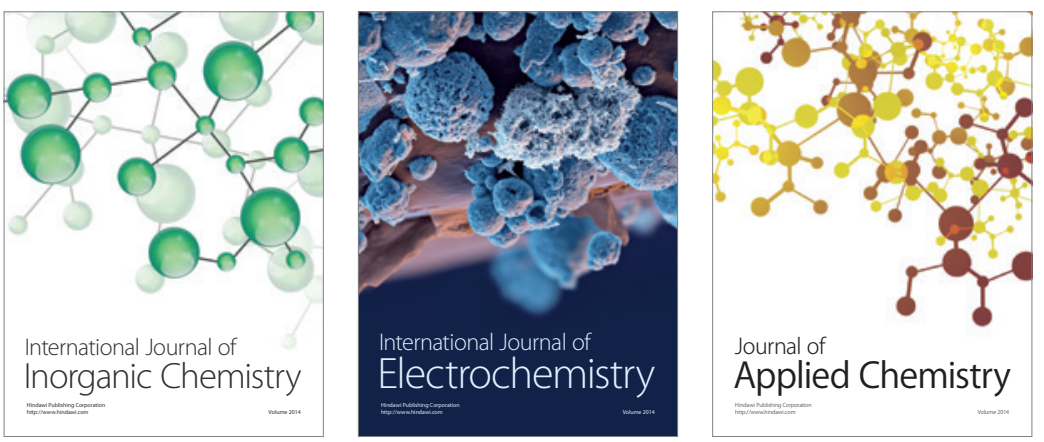

Journal of

Applied Chemistry
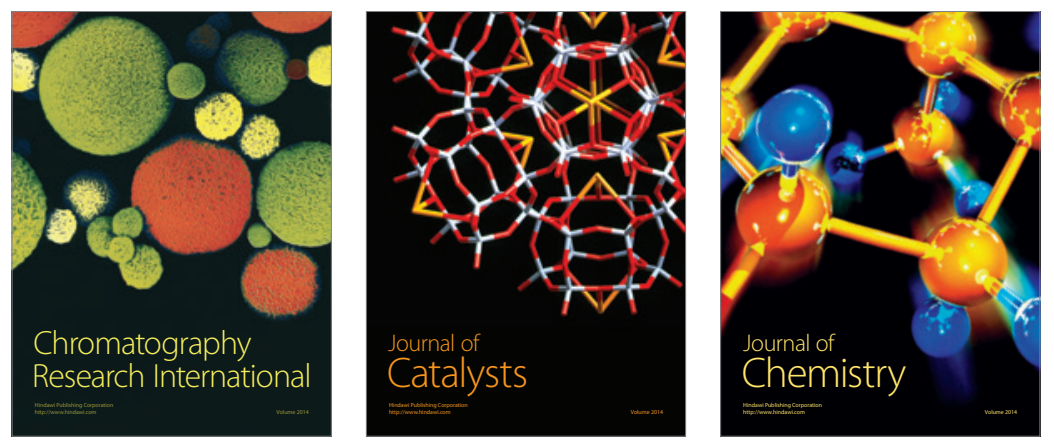
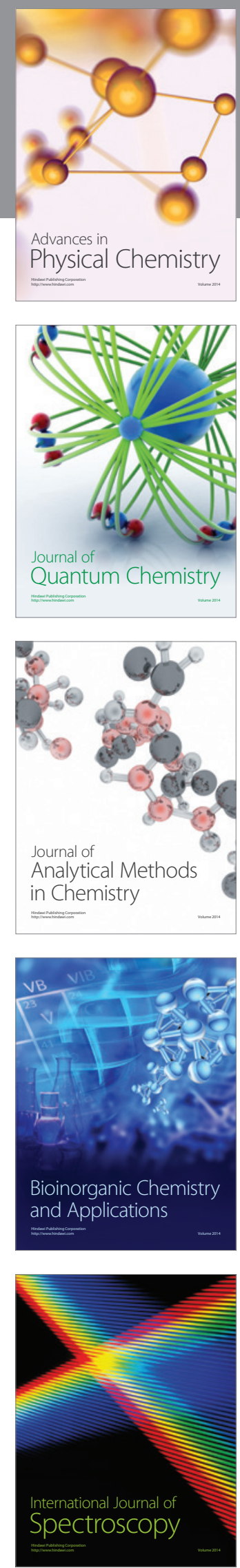